Science, Technology and Development 35 (3): 98-109, 2016

ISSN 0254-6418 / DOI: 10.3923/std.2016.98.109

(C) 2016 Pakistan Council for Science and Technology

\title{
Biological Monitoring of Harnoi Stream Water Quality, Abbottabad, North Pakistan
}

\author{
${ }^{1}$ Javeria Farooq, ${ }^{1}$ Farhana Maqbool, ${ }^{1}$ Muhammad Nasir Khattak, ${ }^{1}$ Saira Gul, \\ ${ }^{2}$ Anees Fatima and ${ }^{3}$ Zulfiqar Ahmed Bhatti \\ ${ }^{1}$ Department of Zoology, Hazara University, Garden Campus, Mansehra 21300, Pakistan \\ ${ }^{2}$ Department of Microbiology, Abbottabad University of Science and Technology, Pakistan \\ ${ }^{3}$ Department of Environmental Sciences, COMSATS Institute of Information Technology, \\ Abbottabad 22060, Pakistan
}

\begin{abstract}
Harnoi stream water quality is severely affected by urban population activities, which resides nearby the stream. The present study was conducted for the assessment of various stream water sites. The aim of the study was to check the effect of various point and nonpoint sources of pollution, on the stream water quality. The study area was divided into three main sites, upstream, polluted and downstream site. These three sites were combined together at river 'Dorr', near Havalian, which ultimately mix with river Indus at Tarbela. Main assessment biological parameters included algal, macro invertebrates, bacteriological and fungal analysis. Other physicochemical parameters included pH, temperature, electrical conductivity, Total Dissolved Solids (TDS), Dissolved Oxygen (DO), $\mathrm{NaCl}$ and turbidity. Higher conductivity value of $680 \mu \mathrm{S} \mathrm{cm}^{-1}$ was found in the month of October, which was higher in polluted site in all 8 months. The TDS higher value of $497 \mathrm{ppm}$ was found in the month of October but the values were below Pak NEQS. Harnoi stream was dominated by Cyanobacteria and Oscillatoria. Macro-invertebrate at pollutant stream site included tolerant species, such as, tubifex, plectus, leech, sewage fly, dero, snails, midge fly larva, black fly larva and carp. Higher gram negative bacterial count showed fecal contamination, which is vulnerable for the stream water quality. It is concluded from the results obtained that, some immediate remediation strategies, like, wetland construction and growth of pollution control plants, are necessary to control the situation.
\end{abstract}

Key words: Biological parameters, macroinvertebrates, harnoi stream, turbidity, algal analysis

\section{INTRODUCTION}

Biological monitoring of fresh water is the use of biological responses to assess changes in the water bodies that generally change due to anthropogenic causes. It is a valuable assessment tool that is receiving increased use in water quality monitoring programmes of all types (Phillips and Rainbow, 1993; Batiuk et al., 1992). The biological monitoring involves a low-cost and uncomplicated method for developing a picture of a stream's health. By collecting and analyzing key indicator species of aquatic insects, one can obtain an understanding of the general condition of a stream (EPA., 2003). Biological monitoring often appears to be more appropriate in the assessment of pollution of aquatic ecosystems than traditional chemical evaluation of water quality (Thiebaut et al., 2006). Species diversity also declined dramatically in polluted sites e.g., Daphnia, which is normally prominent in clear water and vegetated site are replaced by smaller zooplankton, such as Bosmina of order cladocera and several rotifer species (Chow-Fraser et al., 1998).
Because of the constant growth of the world population, the demand of freshwater is increasingly high, especially in the developing countries. At the beginning of 2000, it was estimated that over 1 billion people had no direct access to potable water and $40 \%$ of the world population could not afford freshwater for minimum personal hygiene (Bonanno and Lo Giudice, 2010).

Two main sources of pollution are point sources and nonpoint sources. Point sources are those that arise from a known point, such as, pipe from which a pollutant may enter into stream. Nearly every city, town and waterside settlement discharge some type of pollution to surface waters. Everyday activities, such as, laundry, flushing the toilet and using the in-sink garbage disposal add chemical and microbial pollutants to household waste water. On the other hand, nonpoint sources cannot be traced to a specific point, such as, an outfall pipe (Ball, 2001). Streams are basically polluted by municipal solid wastes, which contain high levels of heavy metals and physical and biological contaminants (Farrell and Jones, 2009). In healthy streams, all feeding groups of macro invertebrates are present but in degraded water environments,

Corresponding Author: Zulfiqar Ahmed Bhatti, Department of Environmental Sciences, 
some feeding groups might be absent or having low relative abundance and, generally, with one or two groups dominating the community (Gamito and Furtado, 2009).

The objectives of the current research include monthly monitoring of the seasonal, biological and physicochemical variations of the Harnoi stream, where stream water quality was checked for the first time. This study has been used to check the fitness of water on "Clean water Act" that restricts fishable and swimmable water quality.

\section{MATERIALS AND METHODS}

Study area: The study area was Harnoi stream, located in the Southern part of Abbottabad (Fig. 1). Harnoi stream was characterized by all four seasons, winter from October to March, spring from April to May, summer from May to August, fall from November to December and rainfall from July to August. This stream supplies water to local community and then discharges it into river Dorr. This river water is largely used by the local farmers for irrigation, bathing and swimming. The three sites were upstream site: Karla, $10 \mathrm{~km}$ up from polluted area, middle polluted site: Present under Harnoi bazaar bridge and downstream site near Dhamtour, $10 \mathrm{~km}$ below from polluted site. Random sampling was performed and $1 \mathrm{~L}$ was collected in clean plastic bottle for physicochemical analysis and $100 \mathrm{~mL}$ in sterilized bottle for microbiological parameters.

Physicochemical analysis: The physical parameters, like, electrical conductivity, Total Dissolved Solids (TDS) and $\mathrm{NaCl}$ concentration, were determined, using Conductivity/TDS meter, Microprocessor HI 9835. Dissolved Oxygen (DO) and turbidity were calculated, using dissolved oxygen meter, Microprocessor Auto Cal
HI 9145. Temperature and $\mathrm{pH}$ were calculated, using HANNA sensor checker. All the parameters were checked in the field and then in the laboratory for comparative analysis (Maqbool et al., 2011).

Algae analysis: Algal growths are usually visible to naked eye as vivid green or blue green growths and occasionally less than 10x hand held lens. Algal samples were scraped from stones and sediments with using clean forceps. They were also collected from water surface by hand or filters. They were then removed into sterile polythene bags. Algal and cyanobacterial samples were then examined microscopically within $24 \mathrm{~h}$ of collection. Anything green and stringy was classified as an alga. The results were then examined, using algal identification sheet.

Macro-invertebrates analysis: Sites were chosen that had gravelly bottoms, which were housing oodles of macro-invertebrates and to ensure consistency among sites. Samples were collected, using a kick net, which was placed downstream from the test site. Then using a foot, the ground was disturbed in approximately a two square feet area. The net was then swiped through the dusty water to collect any macro-invertebrates that were displaced into water column. The net was then emptied into a small plastic container, so that its contents could be adequately shifted through in order to count the bugs. Samples were collected into white trays, keeping each substrate separate. With the help of magnifying lens, the macro-invertebrates were categorized into taxonomic groups, according to sheet taxa, which was used for identification. Once the bugs were counted and recorded, the whole sample was returned to the water. This process was repeated six times at each of the three sites (Aazami et al., 2015).

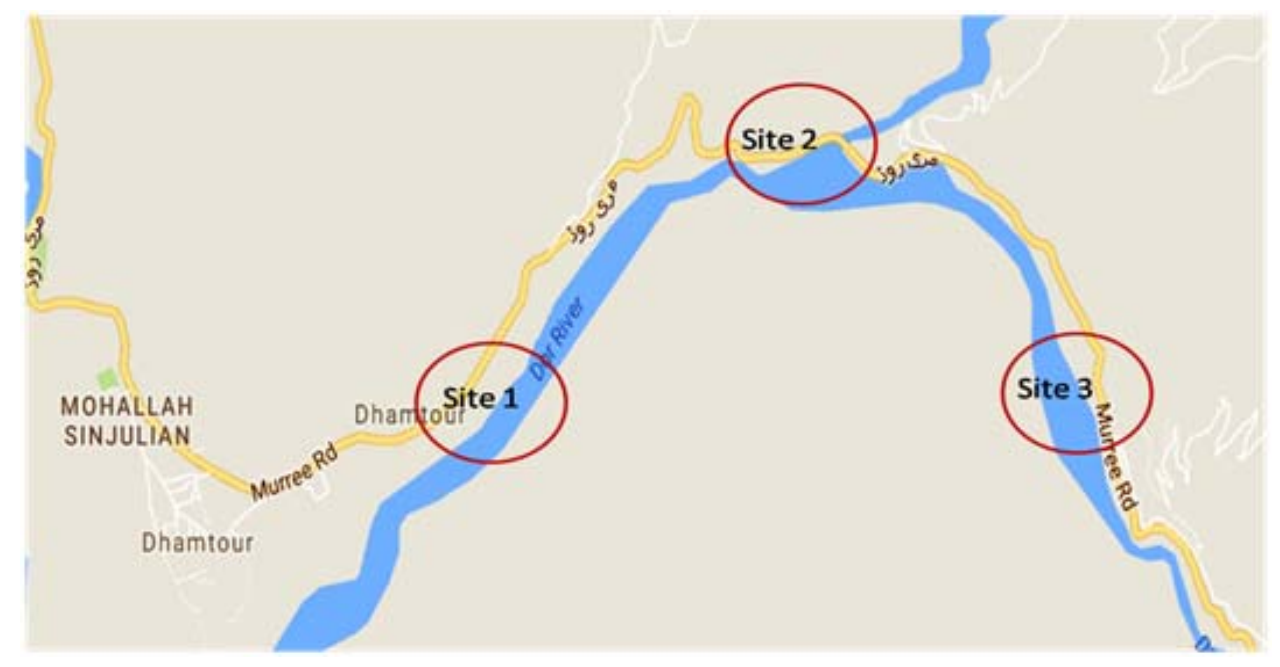

Fig. 1: Sampling site image: Site 1 in red circle is downstream, 2 is polluted and 3 is upstream site (Google map) 
Bacteriological analysis: Samples were collected and necessary dilutions were made. Nutrient agar and Eosin Methylene Blue (EMB) agar plates were used for the total bacterial count and for Coliform group of gram negative organisms, respectively. Agar plates were incubated for $24 \mathrm{~h}$ at $35^{\circ} \mathrm{C}$. EMB is a specific growth medium for Gram negative. On this medium $E$. coli gives green metallic sheen. The measurement is expressed as Colony Forming Unit (CFU) per $100 \mathrm{~mL}$ of water sample and aseptic conditions were maintained throughout the procedure.

Fungal analysis: Sabouraud dextrose agar (SDA) media was used for fungal analysis. Samples were collected and necessary dilutions were made and Lactophenol cotton blue solution was used for staining.

\section{RESULTS AND DISCUSSION}

Physicochemical analysis of stream water quality: Figure 2 shows monthly $\mathrm{pH}$ variation of three sampling sites of Harnoi stream. Water pH varies from 6.1-9, the low $\mathrm{pH}$ was observed at upstream site in October, which may be related to other factors, like low DO concentration, dark shadow, which enhance the fungus growth at the site.

The surface water temperature of spring and stream varied considerably during different months of the year. The value of minimum water temperature was found to be $9.3^{\circ} \mathrm{C}$ at upstream site in the month of December, while maximum temperature was recorded $27.6^{\circ} \mathrm{C}$ in May at polluted site, due to greater solar radiations, clear atmosphere and organic waste decomposition (Fig. 3). Alkaline $\mathrm{pH}$ was observed in the polluted sample during all sampling months. $\mathrm{pH}$ of water is important, because it affects the solubility and availability of nutrients and how can they be utilized by aquatic organisms. Temperature is a critical water quality parameter and it directly influences the amount of DO, which is available to aquatic organisms. Water temperature that exceeds $18^{\circ} \mathrm{C}$ has a deleterious effect on several fish species in the stream.

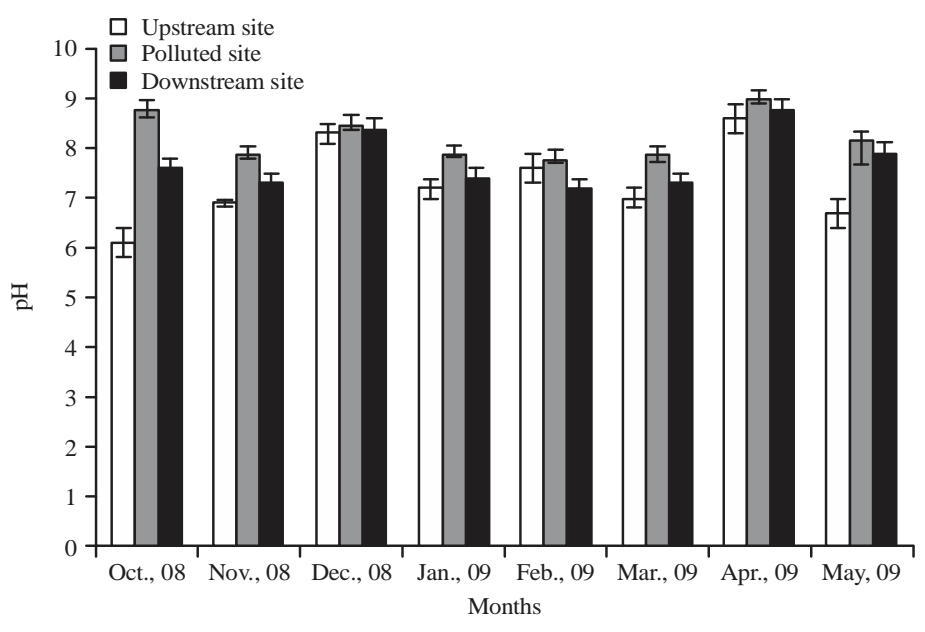

Fig. 2: Monthly $\mathrm{pH}$ variation of three sampling sites of Harnoi stream

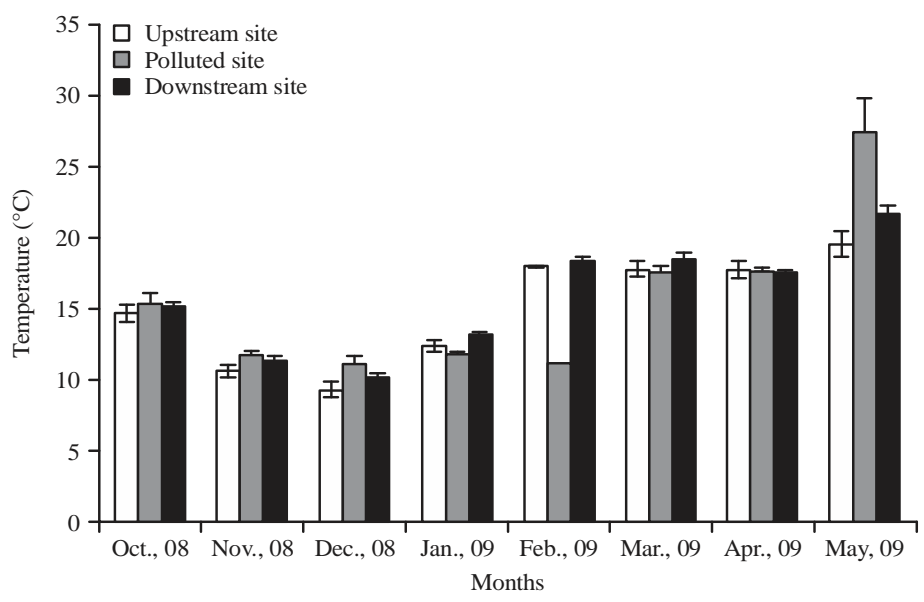

Fig. 3: Monthly temperature variation of 3 sampling sites of Harnoi stream 


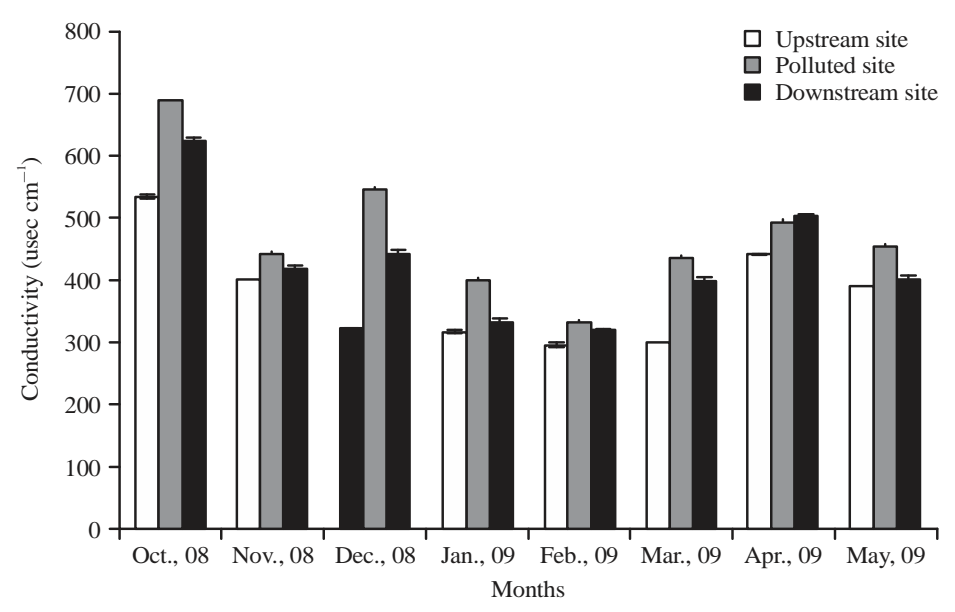

Fig. 4: Monthly conductivity variations of three sampling sites of Harnoi stream

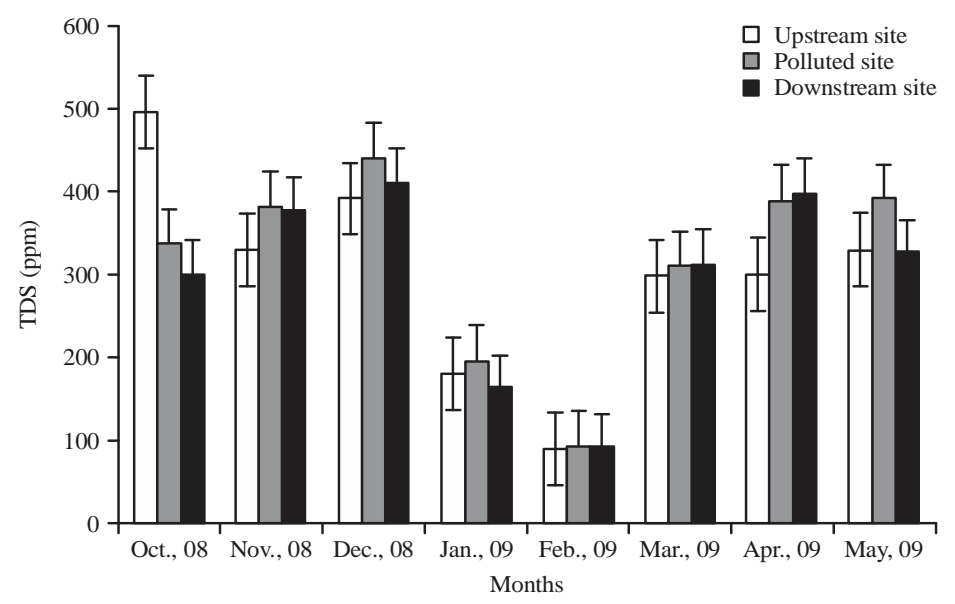

Fig. 5: Monthly TDS variations of three sampling sites of Harnoi stream

A higher conductivity value of $680 \mu \mathrm{S} \mathrm{cm} \mathrm{cm}^{-1}$ was found in the month of October, which was higher in polluted site during 8 months of the year (Fig. 4). A higher TDS value of 497 ppm was found in the month of October, but the values were below Pak NEQS and considered in the TDS range of good water palatability (Fig. 5) (Maqbool et al., 2013).

Figure 6 shows that month of May has low DO at the polluted site, which was lower than other site in around all months. Lower DO values were due to more organic waste decomposition, high temperature and salinity, which releases oxygen from the stream water. The month of December also indicates low values, because this sampling was done in the cloudy weather for the last several days, so the respiring plants and other microorganisms utilized the available DO. Turbidity values were below Pak NEQS, it was the safest range of 5.8-16.5 NTU (Fig. 7). The NaCl concentration was high in the month of December and April, due to low rainfall, which accumulates the minerals (Fig. 8). As the concentration of $\mathrm{NaCl}$ increased in polluted sample, its ionic strength also increased. TDS and conductivity values were within the permissible limits (NWQMP., 2007). Conductivity is the ability of water to conduct an electrical current and is an indirect measure of the ion concentration. The greater the ions present, the more electricity can be conducted by water. Turbidity is a measure of the clarity of water. It is the amount of solids suspended in water and can be in the form of minerals or organic matter.

As, the month of January was cold and DO level was high during these months, the polluted samples show mostly very low level of $\mathrm{DO}$, as it was high temperature and various chemical pollutants decrease the oxygen level. If water is too warm, there may not be enough oxygen in it. The ability of water to hold oxygen in solution is inversely proportional to the temperature of water. 


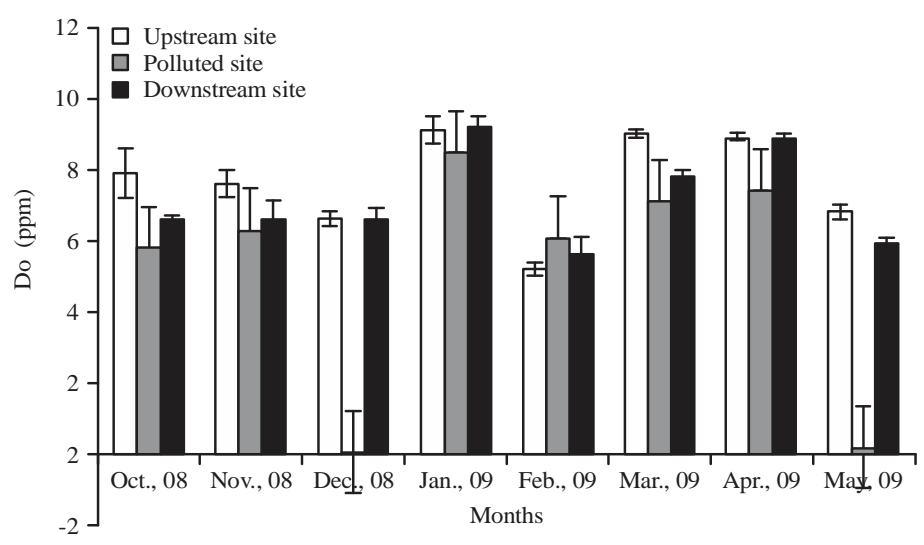

Fig. 6: Monthly dissolved oxygen variations of three sampling sites of Harnoi stream

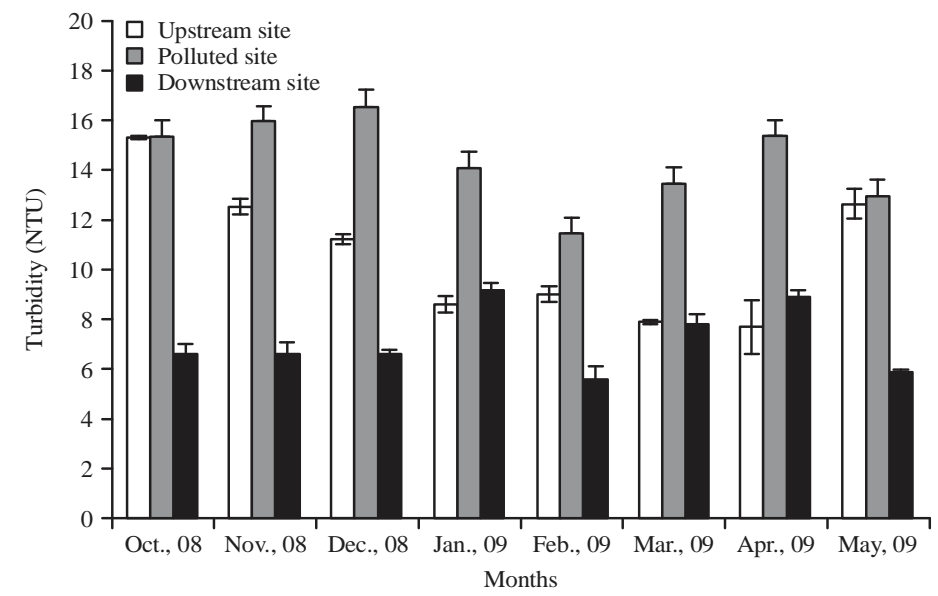

Fig. 7: Monthly turbidity variations of three sampling sites of Harnoi stream

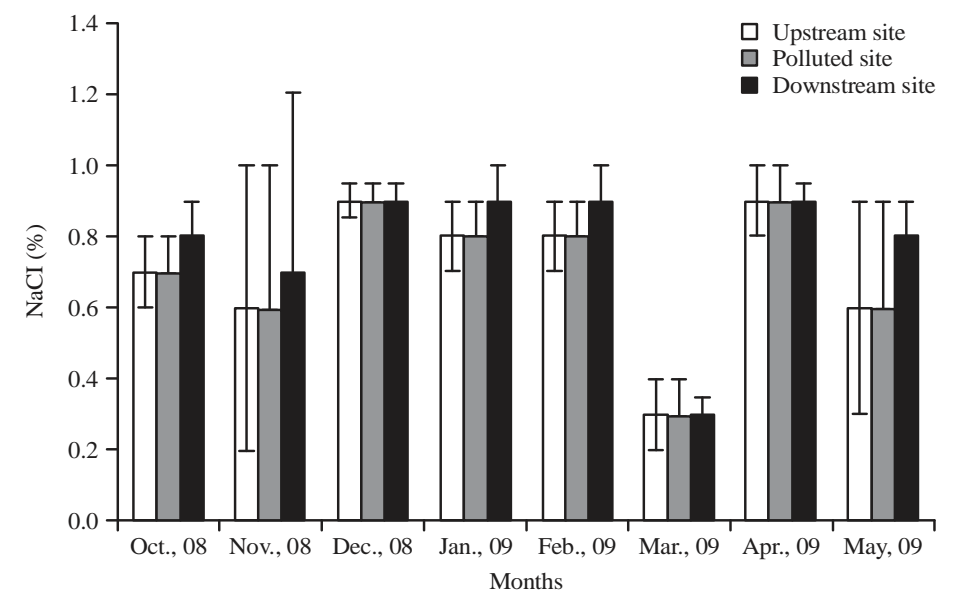

Fig. 8: Monthly $\mathrm{NaCl}$ variations of three sampling sites of Harnoi stream

Seasonal Algal variations of different sites: Table 1 illustrates different kinds of algae present in Harnoi stream and the month of May was ideal for them, due to high temperature, warmer water, cloudless days and lack of rainfall.
Harnoi stream was dominated by Cyanobacteria and Oscillatoria, especially, during the months of January, February and December. This is because they have wide adaptability to extreme environmental factors, like low temperature, desiccation and above 
Sci. Technol. Dev., 35 (3): 98-109, 2016

Table 1: Monthly algal variation of three sampling sites

\begin{tabular}{|c|c|c|c|}
\hline Months & Upstream site & Polluted site & Downstream site \\
\hline \multirow[t]{7}{*}{ Oct., 8} & Rhizoclonium, & Spirogyra & Volvox \\
\hline & Aphanizomenon & Nitzschia & Mougeotia \\
\hline & (Cyanobacteria) & Oscillatoria & Navicula \\
\hline & Dichotomosiphon & Chlamydomonas & Chlamydomonas \\
\hline & & Arthrospira & Lepocinclis \\
\hline & & Stigeoclonium & \\
\hline & & Desmodesmus & \\
\hline \multirow[t]{5}{*}{ Nov., 8} & Ulothrix & Nitzschia & Oscillatoria \\
\hline & Oscillatoria & Phormidium & Euglena \\
\hline & Navicula & Desmodesmus & Mougeotia \\
\hline & Phacotus & Oscillatoria & Lepocinclis \\
\hline & & Euglena & \\
\hline \multirow[t]{4}{*}{ Dec., 8} & Rhizoclonium & Phormidium & Navicula \\
\hline & Aphanizomenon & Oscillatoria & Mougeotia \\
\hline & Dichotomosiphon & Chlorogonium & Ulothrix \\
\hline & (Yellow-green algae) & Stigeoclonium & Pandorina \\
\hline \multirow[t]{5}{*}{ Jan., 9} & Navicula & Spirogyra & Spirogyra \\
\hline & Ulothrix & Phacus & Oscillatoria \\
\hline & Oedogonium & Lyngbya & Palmella \\
\hline & Lyngbya & Palmella & Chlamydomonas \\
\hline & & Chlamydomona & \\
\hline \multirow[t]{6}{*}{ Feb., 9} & Dichotomosiphon & Oscillatoria & Volvox \\
\hline & Ulothrix & Lyngbya & Navicula \\
\hline & Oscillatoria & Spirogyra & Ulothrix \\
\hline & & Chlorella & Lyngbya \\
\hline & & Desmodesmus & Desmodesmus \\
\hline & & Lepocinclis & \\
\hline \multirow[t]{7}{*}{ Mar., 09} & Navicula & Chlorogonium & Navicula \\
\hline & Ulothrix & Stigeoclonium & Ulothrix \\
\hline & Oedogonium & Oscillatoria & Chlamydomonas \\
\hline & Volvox & Euglena & Stigeoclonium \\
\hline & & Lyngbya & Euglena \\
\hline & & Desmodesmus & \\
\hline & & Phacus & \\
\hline \multirow[t]{8}{*}{ Apr., 9} & Lyngbya & Lyngbya & Palmella \\
\hline & Cladophora & Palmella & Chlamydomonas \\
\hline & Microcoleus & Chlamydomonas & Volvox \\
\hline & Dichotomosiphon & Stigeoclonium & Mougeotia \\
\hline & & Oscillatoria & Nitzschia \\
\hline & & Nitzschia & Lepocinclis \\
\hline & & Desmodesmus & Euglena \\
\hline & & Phacus & \\
\hline \multirow[t]{8}{*}{ May, 9} & Navicula & Chlamydomonas & Volvox \\
\hline & Ulothrix & Stigeoclonium & Mougeotia \\
\hline & Oedogonium & Oscillatoria & Navicula \\
\hline & Volvox & Chlorogonium & Ulothrix \\
\hline & & Euglena & Nitzschia \\
\hline & & Lepocinclis & Euglena \\
\hline & & Phacus & Desmodesmus \\
\hline & & Desmodesmus & \\
\hline
\end{tabular}

optimal and solar radiation. Table 1 shows that many kinds of algae were present in Harnoi stream and the month of May was ideal for them, due to higher temperature, warmer water, cloudless days and lack of rainfall, all of which contribute to the conditions which encourage algal growth and reproduction. All this led to odor and taste issues in stream water. These algae are a natural part of biodiversity, which contributes to the biological food chain. Some of these algae have the capacity to produce algal toxins, which may, at certain concentrations, cause some health concerns to those, who come into contact with water. Some of these algae may pose a risk for recreational users and were aesthetically unappealing. These algae were also involved in clogging pipes and filter lines. The greater the level of nutrients in the stream, the more food exists for algae and other vegetation to grow. 
Sci. Technol. Dev., 35 (3): 98-109, 2016

Table 2: Monthly macro invertebrate variations of three sampling sites

\begin{tabular}{|c|c|c|c|}
\hline Months & Upstream site & Polluted site & Downstream site \\
\hline \multirow[t]{5}{*}{ Oct., 8} & Mayfly nymph & Tubifex & Tubifex \\
\hline & Fairy shrimp & Plectus & Dero \\
\hline & Stonefly nymph & Leech & Midge larvae \\
\hline & Daphnia & Midge larvae & Diving beetle \\
\hline & Crayfish & Diving beetle & Beetle larvae \\
\hline \multirow[t]{7}{*}{ Nov., 8} & Philodina (Rotifer) & Limnaea & Limnaea \\
\hline & Stonefly nymph & Tubifex & Dero \\
\hline & Mayfly nymph & Dero & Flatworm \\
\hline & Caddisfly larvae & Midge larvae & Mussel \\
\hline & Spider & Diving beetle & Sowbugs \\
\hline & Amphipod & & Beetle larvae \\
\hline & Daphnia & & \\
\hline \multirow[t]{5}{*}{ Dec., 8} & Mayfly nymph & Limnaea & Dero \\
\hline & Fairy shrimp & Tubifex & Flatworm \\
\hline & Housefly larvae (Musca) & Dero & Mussel \\
\hline & Dero & Midge larvae & Sowbugs \\
\hline & Daphnia & Diving beetle & Scuds \\
\hline \multirow[t]{6}{*}{ Jan., 9} & Mayfly nymph & Limnaea & Limnaea \\
\hline & Fairy shrimp & Tubifex & Sowbugs \\
\hline & Daphnia & Dero & Scuds \\
\hline & Stonefly nymph & Midge larvae & Beetle larvae \\
\hline & Mayfly nymph & Diving beetle & \\
\hline & Small beetles & & \\
\hline \multirow[t]{7}{*}{ Feb., 9} & Mayfly nymph & Scud & Pelomyxa \\
\hline & Fairy shrimp & Dero & Fairy shrimp \\
\hline & Stonefly nymph & Limnaea & Daphnia \\
\hline & Water penny & Midge larvae & Scud, Dero \\
\hline & Riffle beetle & Diving beetle & Damselfly nymph \\
\hline & & & Limnaea \\
\hline & & & Sowbugs \\
\hline \multirow[t]{6}{*}{ Mar., 9} & Damselfly nymph & Tubifex & Damselfly nymph \\
\hline & Crayfish & Limnaea & Limnaea \\
\hline & Mayfly nymph & Midge larvae & Sowbugs \\
\hline & Fairy shrimp & Diving beetle & Scuds \\
\hline & Dragonfly nymph & Scud & Beetle larvae \\
\hline & Daphnia & Dero & Sowbugs \\
\hline \multirow[t]{7}{*}{ Apr., 9} & Kellicottia (Rotifer) & Planaria & Planaria \\
\hline & Mayfly nymph & Kellicottia & Daphnia \\
\hline & Dragonfly nymph & Tubifex & Kellicottia \\
\hline & Small beetles & Water scorpion & Dragonfly nymph \\
\hline & Caddisfly larvae & Mosquito pupa & Clams \\
\hline & Spider & Leeches & Sowbugs \\
\hline & Amphipod & Blackfly larvae & Scuds \\
\hline \multirow[t]{6}{*}{ May, 9} & Daphnia & Housefly larvae & Planaria \\
\hline & Housefly larvae & Planaria & Plectus \\
\hline & Stonefly nymph & Plectus & Sowbugs \\
\hline & Crayfish & Mosquito pupa & Scuds \\
\hline & Caddisfly larvae & Leeches & Beetle larvae \\
\hline & Spider & Blackfly larvae & \\
\hline
\end{tabular}

Seasonal macro invertebrate variation of different sites: Table 2 shows that upstream and downstream had the greatest diversity and the stream with the greatest human intrusion (polluted site) had the least diversity.

The upstream site had many intolerant species, which shows that the stream is relatively free of pollutants. For example, stoneflies, mayflies, caddisflies, dobsonfly, water penny and riffle beetle are very sensitive to most pollutants and are dependent upon the stream DO level remaining above a certain point. Conversely pollutant stream site was primarily inhabited by pollution tolerant species, such as, tubifex (sludgeworm), plectus (roundworm), leech (segmented worm), sewage fly, dero, snails, midge fly larva, black fly larva and carp. The absence of different species of mussels was also representing the organic pollution at this site; similar 
findings were also observed for the polluted site of Velika Morava River (Tomovic et al., 2012). Macro invertebrates are an important indicator of stream quality because they are relatively sensitive and can be easily impacted by pollutants or other disturbances. The goal of macro-invertebrate study was to test whether their diversity changes with the increased human development in the surrounding area of stream or not. It was demonstrated that stoneflies were no longer present in the polluted site, where they once were, because the pollutant stream dissolved oxygen content had decreased. Tubifex were more abundant in polluted site, which was the indicator of sewage pollution; their abundance was high in another study in autumn, due to the absence of rainfall and low natural filtration at polluted site (Markovic et al., 2015). The productive areas for macro-invertebrates are riffles, leaf packs, soft sediments and root/bank habitat. Freshwater shrimp taxa dominated the faunal biomass of upstream and downstream, however, their role in community organization is unclear but they may cause significant reductions in sediment cover on rock substrata, reducing sedimentation and, thus, enhancing understory algal food resources through sediment removal to increase algal bio-volume.

Monthly bacterial and fungal count of different sites: Table 3 shows that few or no fungal growth was found in the cold months of December, January and February, while during the month of May, fungal diversity increased.

Water quality did not have a significant effect on composition of fungal community. Fungi do not grow at low temperature. Due to their role in energy transfer of streams, it is fundamental to further investigate the effect of pollution on structure and functioning of assemblages of aquatic fungi. Freshwater fungi involved in decay of wood and leafy material, also cause diseases of plants and animals.

In the upstream site, the highest total bacterial count of 910 and $950 \mathrm{CFU} \mathrm{mL} \mathrm{m}^{-1}$ was observed in the month of October and May, respectively. The highest gram negative load on EMB agar was $780 \mathrm{CFU} \mathrm{mL}^{-1}$, observed in the month of October in the up-stream site, due to high temperature, which increased the biodegradable activity and rainfall, thereby, mixing the organic waste significantly into the stream. The lowest total bacterial count in the range of $100-310 \mathrm{CFU} \mathrm{mL}^{-1}$ was found in the months of December, January and February, due to low microbial activity (Table 4).

Polluted samples show total bacterial count in the range of $7.8 \times 10^{4}-1.2 \times 10^{5} \mathrm{CFU} \mathrm{mL}^{-1}$ in the month of December and May, respectively. The highest bacterial load, in May and June, was due to warm weather, which increased the decomposition and the rain water, which mixed the solid waste of Harnoi area into the main stream of Harnoi. Table 5 shows that the total polluted site includes three different colored colonies obtained on EMB agar, pink colored colonies were of fecal streptococci, pink colonies with green metallic sheen were of E. coli and blue colonies might be of fecal coliforms. These colonies were in the range of $5.8 \times 10^{4}-1.43 \times 10^{5} \mathrm{CFU} \mathrm{mL}^{-1}$. Downstream site showed almost same bacterial count as up-stream site, which might be due to self purification of running stream water.

Downstream site showed the highest total bacterial count in the month of May, October and November, due to warm climate. On EMB agar, bacterial load was in the range of $10^{2}-8.1 \times 10^{2} \mathrm{CFU} \mathrm{mL}^{-1}$ (Table 6).

Table 3: Monthly fungal variations of three sampling sites

\begin{tabular}{|c|c|c|c|}
\hline Months & Upstream site & Polluted site & Downstream site \\
\hline Oct., 8 & $\begin{array}{l}\text { Alternaria, grayish green colony, } \\
\text { rapidly swarming over entire plate }\end{array}$ & $\begin{array}{l}\text { Mucor, white colored cottony colony, } \\
\text { rapidly swarming over entire plate }\end{array}$ & Very low fungal growth \\
\hline Nov., 8 & Very low fungal growth & $\begin{array}{l}\text { Rhizopus, white colored cottony colony, } \\
\text { rapidly swarming over entire plate }\end{array}$ & Very low fungal growth \\
\hline Dec., 8 & $\begin{array}{l}\text { Alternaria, grayish green colony, } \\
\text { rapidly swarming over entire plate }\end{array}$ & Very low fungal growth & Very low fungal growth \\
\hline Jan., 9 & Very low fungal growth & Very low fungal growth & $\begin{array}{l}\text { Mucor, white colored cottony colony, } \\
\text { rapidly swarming over entire plate }\end{array}$ \\
\hline Feb., 9 & Very low fungal growth & $\begin{array}{l}\text { Rhizopus, white colored cottony } \\
\text { colony, rapidly swarming over entire plate }\end{array}$ & Very low fungal growth \\
\hline Mar., 9 & $\begin{array}{l}\text { Mucor, white colored cottony colony, } \\
\text { rapidly swarming over entire plate }\end{array}$ & $\begin{array}{l}\text { Mucor, white colored cottony colony, } \\
\text { rapidly swarming over entire plate }\end{array}$ & Fusarium, wooly, pink and white colony \\
\hline Apr., 9 & $\begin{array}{l}\text { Mucor, white colored cottony colony, } \\
\text { rapidly swarming over entire plate }\end{array}$ & $\begin{array}{l}\text { Mucor, white colored cottony colony, } \\
\text { rapidly swarming over entire plate }\end{array}$ & Very low fungal growth \\
\hline May, 9 & $\begin{array}{l}\text { Alternaria, grayish green colony, } \\
\text { rapidly swarming over entire plate }\end{array}$ & Fusarium, wooly, pink and white colony & $\begin{array}{l}\text { Alternaria, grayish green colony, rapidly } \\
\text { swarming over entire plate }\end{array}$ \\
\hline
\end{tabular}


Sci. Technol. Dev., 35 (3): 98-109, 2016

Table 4: Seasonal bacterial variations of up-stream site

\begin{tabular}{|c|c|c|c|c|}
\hline \multirow[b]{2}{*}{ Months } & \multicolumn{2}{|l|}{ Nutrient agar } & \multicolumn{2}{|l|}{ EMB Agar } \\
\hline & Colonial morphology & $\mathrm{CFU} \times 10^{3} / 100 \mathrm{~mL}$ & Colonial morphology & $\mathrm{CFU} \times 10^{3} / 100 \mathrm{~mL}$ \\
\hline \multirow[t]{5}{*}{ Oct., 8} & Off white, circular, convex, large & 50 & Pink with metallic green sheen, circular, convex, large & 11 \\
\hline & Small pin pointed off white & 20 & Blue, circular, convex & 20 \\
\hline & Yellow, irregular, raised & 16 & Blue, circular, flat, large & 16 \\
\hline & Orange, circular, convex, large & 5 & Purplish pink, circular, convex, small & 22 \\
\hline & & $(91)^{*}$ & Pink, large, mucoid & $\begin{array}{l}9 \\
(78)\end{array}$ \\
\hline \multirow[t]{4}{*}{ Nov., 8} & Offwhite, circular, convex, large & 48 & Purplish pink, circular, convex, small & 33 \\
\hline & Small pin pointed off white & 33 & Blue, circular, flat, large & 23 \\
\hline & Orange, circular, convex, large & 8 & Pink with metallic green sheen, circular, convex, large & 5 \\
\hline & & (89) & & $\begin{array}{l}3 \\
(64)\end{array}$ \\
\hline \multirow[t]{3}{*}{ Dec., 8} & Offwhite, irregular, large & 6 & Purplish pink, circular, convex, large & 7 \\
\hline & Orange, circular, convex, large & 4 & Blue, circular, flat, small & 9 \\
\hline & & (10) & Pink with metallic green sheen, circular, convex, large & $\begin{array}{l}2 \\
(18)\end{array}$ \\
\hline \multirow[t]{3}{*}{ Jan., 9} & Offwhite, circular, raised, small & 9 & Pink with metallic green sheen, & 3 \\
\hline & Yellow, irregular, raised & 4 & circular, convex, large & 7 \\
\hline & & (13) & Blue, circular, convex, small & $(10)$ \\
\hline \multirow[t]{4}{*}{ Feb., 9} & Yellow, irregular, raised & 12 & Pink with metallic green sheen, circular, convex, large & 6 \\
\hline & Creamy, circular, flat & 3 & Purplish pink, circular, convex, large & 8 \\
\hline & Offwhite, irregular, large & 9 & & $(14)$ \\
\hline & Yellow, irregular, raised & $\begin{array}{l}7 \\
(31)\end{array}$ & & \\
\hline \multirow[t]{2}{*}{ Mar., 9} & Offwhite, circular, convex, large & 17 & Pink with metallic green sheen, circular, convex, small & 11 \\
\hline & Small pin pointed offwhite & $\begin{array}{l}11 \\
(28)\end{array}$ & Purplish pink, circular, convex, large & $\begin{array}{l}5 \\
(16)\end{array}$ \\
\hline \multirow[t]{3}{*}{ Apr., 9} & Offwhite, circular, convex, large & 26 & Purplish pink, circular, convex, large & 33 \\
\hline & Small pin pointed offwhite & 22 & Pink with metallic green sheen, circular, convex, large & 4 \\
\hline & & (48) & Pink, large, mucoid & $\begin{array}{l}11 \\
(48)\end{array}$ \\
\hline \multirow[t]{4}{*}{ May, 9} & Yellow, irregular, raised, large & 31 & Light purple, circular, flat, small & 36 \\
\hline & Opaque white, large & 23 & Purplish pink, circular, convex, large & 21 \\
\hline & Creamy, circular, flat & 22 & Pink with metallic green sheen, circular, convex, large & 9 \\
\hline & Orange, circular, convex, large & $\begin{array}{l}19 \\
(95)\end{array}$ & Pink, large, mucoid & $\begin{array}{l}8 \\
(74)\end{array}$ \\
\hline
\end{tabular}

*Values in parentheses show total number of colonies on agar plate

Table 5: Seasonal bacterial variations of polluted site

\begin{tabular}{|c|c|c|c|c|}
\hline \multirow[b]{2}{*}{ Months } & \multicolumn{2}{|l|}{ Nutrient agar } & \multicolumn{2}{|l|}{ EMB Agar } \\
\hline & Colonial morphology & $\mathrm{CFU} \times 10^{5} / 100 \mathrm{~mL}$ & Colonial morphology & $\mathrm{CFU} \times 10^{3} / 100 \mathrm{~mL}$ \\
\hline \multirow[t]{6}{*}{ Oct., 8} & Off white, circular, convex, large & 31 & Pink with metallic green sheen, circular, convex, large & 20 \\
\hline & Small pin pointed off white & 29 & Blue, circular, convex & 19 \\
\hline & Yellow, irregular, raised & 15 & Blue, circular, flat, large & 21 \\
\hline & Orange, circular, convex, large & 23 & Purplish pink, circular, convex, small & 22 \\
\hline & & $(98)^{*}$ & Pink, large, mucoid & 29 \\
\hline & & & Brownish purple & $\begin{array}{l}18 \\
(129)\end{array}$ \\
\hline \multirow[t]{5}{*}{ Nov., 8} & Yellow, irregular, raised & 20 & Purplish pink, circular, convex, small & 31 \\
\hline & Off white, circular, convex, large & 33 & Blue, circular, flat, large & 23 \\
\hline & Small pin pointed off white & 23 & Pink with metallic green sheen, circular, convex, large & 24 \\
\hline & Orange, circular, convex, large & 28 & Pink, large, mucoid & 19 \\
\hline & & (108) & Brownish purple & $\begin{array}{l}25 \\
(122)\end{array}$ \\
\hline \multirow[t]{4}{*}{ Dec., 8} & Offwhite, irregular, large & 23 & Purplish pink, circular, convex, large & 24 \\
\hline & Orange, circular, convex, large & 25 & Blue, circular, flat, small & 19 \\
\hline & Yellow, irregular, raised & 32 & Pink with metallic green sheen, circular, convex, large & 15 \\
\hline & Creamy, circular, flat & $\begin{array}{l}23 \\
(103)\end{array}$ & & (58) \\
\hline
\end{tabular}


Sci. Technol. Dev., 35 (3): 98-109, 2016

Table 5: Continue

\begin{tabular}{|c|c|c|c|c|}
\hline \multirow[b]{2}{*}{ Months } & \multicolumn{2}{|l|}{ Nutrient agar } & \multicolumn{2}{|l|}{ EMB Agar } \\
\hline & Colonial morphology & $\mathrm{CFU} \times 10^{5} / 100 \mathrm{~mL}$ & Colonial morphology & $\mathrm{CFU} \times 10^{3} / 100 \mathrm{~mL}$ \\
\hline \multirow[t]{4}{*}{ Jan., 9} & Small pin pointed offwhite & 28 & Pink with metallic green sheen, circular, convex, large & 19 \\
\hline & Offwhite, circular, raised, small & 19 & Blue, circular, convex, small & 20 \\
\hline & Yellow, irregular, raised & 31 & Pink, large, mucoid & 16 \\
\hline & & (78) & Brownish purple & $\begin{array}{l}17 \\
(72)\end{array}$ \\
\hline \multirow[t]{5}{*}{ Feb., 9} & Yellow, irregular, raised & 29 & Pink with metallic green sheen, circular, convex, large & 25 \\
\hline & Creamy, circular, flat & 20 & Purplish pink, circular, convex, large & 17 \\
\hline & Offwhite, irregular, large & 29 & Brownish purple & 13 \\
\hline & Yellow, irregular, raised & 13 & Pink, large, mucoid & 20 \\
\hline & Small pin pointed offwhite & $\begin{array}{l}29 \\
(120)\end{array}$ & Blue, circular, flat, small & $\begin{array}{l}21 \\
(96)\end{array}$ \\
\hline \multirow[t]{5}{*}{ Mar., 9} & Offwhite, circular, convex, large & 19 & Pink with metallic green sheen, circular, convex, small & 29 \\
\hline & Small pin pointed offwhite & 24 & Purplish pink, circular, convex, large & 18 \\
\hline & Yellow, irregular, raised & 18 & Pink, large, mucoid & 20 \\
\hline & Creamy, circular, flat & 20 & Brownish purple & 26 \\
\hline & & $(81)$ & Blue, circular, flat, small & $\begin{array}{l}15 \\
(108)\end{array}$ \\
\hline \multirow[t]{5}{*}{ Apr., 9} & Offwhite, circular, convex, large & 26 & Purplish pink, circular, convex, large & 21 \\
\hline & Small pin pointed offwhite & 23 & Pink with metallic green sheen, circular, convex, large & 29 \\
\hline & Yellow, irregular, raised & 29 & Pink, large, mucoid & 19 \\
\hline & Creamy, circular, flat & 18 & Brownish purple & 22 \\
\hline & & (96) & Blue, circular, flat, small & $\begin{array}{l}31 \\
(122)\end{array}$ \\
\hline \multirow[t]{6}{*}{ May, 9} & Yellow, irregular, raised, large & 13 & Light purple, circular, flat, & 25 \\
\hline & Opaque white, large & 23 & small Purplish pink, circular, convex, large & 21 \\
\hline & Creamy, circular, flat & 30 & Pink with metallic green sheen, circular, convex, large & 30 \\
\hline & Orange, circular, convex, large & 19 & Pink, large, mucoid & 23 \\
\hline & & (85) & Blue, circular, flat, small & 24 \\
\hline & & & Brownish purple & $\begin{array}{l}20 \\
(143)\end{array}$ \\
\hline
\end{tabular}

*Values in parentheses show total number of colonies on agar plate

Table 6: Monthly bacterial variations of downstream site

\begin{tabular}{|c|c|c|c|c|}
\hline \multirow[b]{2}{*}{ Months } & \multicolumn{2}{|l|}{ Nutrient agar } & \multicolumn{2}{|l|}{ EMB Agar } \\
\hline & Colonial morphology & $\mathrm{CFU} \times 10^{3} / 100 \mathrm{~mL}$ & Colonial morphology & $\mathrm{CFU} \times 10^{3} / 100 \mathrm{~mL}$ \\
\hline \multirow[t]{8}{*}{ Oct., 8} & Yellow, irregular, raised & 50 & Blue, circular, flat, large & 11 \\
\hline & Orange, circular, convex, large & 20 & Purplish pink, circular, convex, small & 20 \\
\hline & Offwhite, circular, convex, large & 16 & Pink, large, mucoid & 16 \\
\hline & Small pin pointed offwhite & 5 & Pink with metallic green sheen, circular, convex, large & 22 \\
\hline & & $(91)^{*}$ & Blue, circular, convex & 9 \\
\hline & & & Blue, circular, flat, large & (78) \\
\hline & & & Purplish pink, circular, convex, small & \\
\hline & & & Pink, large, mucoid & \\
\hline \multirow[t]{4}{*}{ Nov., 08} & Small pin pointed offwhite & 48 & Purplish pink, circular, convex, small & 33 \\
\hline & Orange, circular, & 33 & Blue, circular, flat, large & 23 \\
\hline & Offwhite, circular, convex, large & 8 & Pink with metallic green sheen, circular, convex, large & 5 \\
\hline & convex, large & (89) & & $(61)$ \\
\hline \multirow[t]{4}{*}{ Dec., 8} & Offwhite, irregular, large & 6 & Purplish pink, circular, convex, large & 7 \\
\hline & Orange, circular, convex, large & 4 & Blue, circular, flat, small & 9 \\
\hline & & (10) & Pink with metallic green sheen, circular, convex, large & 2 \\
\hline & & & & (18) \\
\hline \multirow[t]{3}{*}{ Jan., 9} & Offwhite, circular, raised, small & 9 & Pink with metallic green sheen, circular, convex, large & 3 \\
\hline & Yellow, irregular, raised & 4 & Brownish purple & 7 \\
\hline & & (13) & Blue, circular, convex, small & $(10)$ \\
\hline \multirow[t]{5}{*}{ Feb., 9} & Yellow, irregular, raised & 12 & Pink with metallic green sheen, circular, convex, large & 6 \\
\hline & Creamy, circular, flat & 3 & Brownish purple & 8 \\
\hline & Offwhite, irregular, large & 9 & Purplish pink, circular, convex, large & (14) \\
\hline & Yellow, irregular, raised & 7 & & \\
\hline & & (31) & & \\
\hline
\end{tabular}


Sci. Technol. Dev., 35 (3): 98-109, 2016

Table 6: Continue

\begin{tabular}{lllll}
\hline & Nutrient agar & & EMB Agar & \\
Months & Colonial morphology & CFU $\times 10^{3} / 100 \mathrm{~mL}$ & Colonial morphology & CFU×10 $/ 100 \mathrm{~mL}$ \\
\hline Mar., 9 & Offwhite, circular, convex, large & 17 & Pink with metallic green sheen, circular, convex, small & 11 \\
& Small pin pointed offwhite & 11 & Purplish pink, circular, convex, large & 19 \\
& & $(28)$ & & $(30)$ \\
Apr., 9 & Offwhite, circular, convex, large & 26 & Purplish pink, circular, convex, large & 33 \\
& Small pin pointed offwhite & 22 & Pink with metallic green sheen, circular, convex, large & 4 \\
& & $(48)$ & Pink, large, mucoid & 11 \\
May, 09 & Creamy, circular, flat & 31 & Brownish purple & $(48)$ \\
& Orange, circular, & 23 & Light purple, circular, flat, small Purplish pink, & 36 \\
& Yellow, irregular, raised, large & 22 & circular, convex, large & 21 \\
& Opaque white, large & 19 & Pink with metallic green sheen, circular, convex, large & 9 \\
& convex, large & $(95)$ & Pink, large, mucoid & 8 \\
& & Brownish purple & 7 \\
\end{tabular}

*values in parentheses show total number of colonies on agar plate

\section{CONCLUSION}

Current investigation of different parameters of water quality suggested that the Harnoi stream water is highly polluted by the anthropogenic activities of nearby community including sewage disposal, organic and inorganic solid waste dumping and vehicle washing in the Harnoi stream, which results in the destruction of flora and fauna of this stream. Thus, the surface water cannot harbor the fish and does not provide suitable breeding ground for macro-invertebrates. Enactment of strict legislation for the protection of stream water from disposal of any type of contaminant should be recommended. It is concluded from the results obtained, that some immediate remediation strategies, like, wetland construction or growth of pollution control plants are necessary to control the situation. For future research prospective, it is suggested that more appropriate method of MPN should be used for total coliform count, which comprises fecal and thermo-tolerant separately. One important parameter, i.e., Biological Oxygen Demand (BOD) should also be analyzed.

\section{REFERENCES}

Aazami, J., A. Esmaili-Sari, A. Abdoli, H. Sohrabi and P.J. van den Brink, 2015. Monitoring and assessment of water health quality in the Tajan River, Iran using physicochemical, fish and macroinvertebrates indices. J. Environ. Health Sci. Eng., Vol. 13. 10.1186/s40201-015-0186-y

Ball, P., 2001. Life's Matrix: A Biography of Water. Farrar Straus and Giroux Publ., New York, USA., ISBN-13: 9780520230088, Pages: 417.
Batiuk, R.A., R.J. Orth, K.A. Moore, W.C. Dennison and J.C. Stevenson et al., 1992. Chesapeake Bay submerged aquatic vegetation habitat requirements and restoration targets: A technical synthesis. U.S. Environmental Protection Agency for the Chesapeake Bay Program, Annapolis, MD., USA., December 1992, pp: 1-246.

Bonanno, G. and R. Lo Giudice, 2010. Application of two quality indices as monitoring and management tools of rivers. Case study: The Imera Meridionale River, Italy. Environ. Manage., 45: 856-867.

Chow-Fraser, P., V. Lougheed, V. Le Thiec, B. Crosbie, L. Simser and J. Lord, 1998. Long-term response of the biotic community to fluctuating water levels and changes in water quality in Cootes Paradise Marsh, a degraded coastal wetland of Lake Ontario. Wetland Ecol. Manage., 6: 19-42.

EPA., 2003. Georgia Basin-Puget sound ecosystem indicators report. U.S. Environmental Protection Agency, Washington, DC., USA.

Farrell, M. and D.L. Jones, 2009. Critical evaluation of municipal solid waste composting and potential compost markets. Bioresour. Technol., 100: 4301-4310.

Gamito, S. and R. Furtado, 2009. Feeding diversity in macroinvertebrate communities: A contribution to estimate the ecological status in shallow waters. Ecol. Indicators, 9: 1009-1019.

Maqbool, F., A.H. Malik and Z.A. Bhatti, 2013. Water Quality Analysis of Salhad Stream Abbottabad, Pakistan. LAP Lambert Academic Publishing, Germany, ISBN-13: 978-3-659-33982-0, Pages: 100.

Maqbool, F., Z.A. Bhatti, A.H. Malik, A. Pervez and Q. Mahmood, 2011. Effect of landfill leachate on the stream water quality. Int. J. Environ. Res., 2: 491-500. 
Markovic, V., J. Tomovic, A. Atanackovic, M. Kracun, M. Ilic, V. Nikolic and M. Paunovic, 2015. Macroinvertebrate communities along the Velika Morava River. Turk. J. Zool., 39: 210-224.

NWQMP., 2007. National Water Quality Monitoring Program fifth monitoring report (2005-06). Pakistan Council of Research in Water Resources (PCRWR), Islamabad, Pakistan, June 2007.

Phillips, D.J.H. and P.S. Rainbow, 1993. Biomonitoring of Trace Aquatic Contaminants. Elsevier Science Publications, Barking, UK., Pages: 371.
Thiebaut, G., G. Tixier, F. Guerold and S. Muller, 2006. Comparison of different biological indices for the assessment of river quality: Application to the upper river Moselle (France). Hydrobiologia, 570: 159-164.

Tomovic, J., K. Zoric, M. Kracun, V. Markovic, B. Vasiljevic, V. Simic and M. Paunovic, 2012. Freshwater mussels of the Velika Morava River. Water Resour. Manage., 2: 51-55. 